\title{
ANALYSIS OF EMPLOYEE PERFORMANCE OF BANKING COMPANIES: A CASE IN INDONESIA
}

\author{
Ratnasih Cicih \\ University of Borobudur, Indonesia
}

\section{Zulher}

Bangkinang College of Economics, Indonesia

*E-mail: c.ratnasih1@gmail.com

\begin{abstract}
In this study, analyzing several variables that can affect the performance of banking company employees, among others, organizational culture variables (X1), leadership (X2), employee motivation (X3), compensation (X4), Job security (X5), promotion (X6), reward (X7), and punishment (X8) on the variable performance of banking employees. The analytical method used uses multiple regression that will predict the effect of independent variables that affect the dependent variable. Overall all of the variables are simultaneously significant on the performance variables of banking company employees in Indonesia. Partially there is a significant influence of leadership variable (X2), employee motivation variable (X3), compensation variable (X4), and reward variable (X7) on the performance of banking company employees. As for the organizational culture variable (X1), Job security (X5), promotion (X6), and punishment (X8) it is not significant. Therefore these variables do not need special attention.
\end{abstract}

\section{KEY WORDS}

Employee performance, organizational culture, leadership, employee motivation, compensation, job security, promotion, reward, punishment.

Banking companies in carrying out their activities are tasked with providing services to customers in terms of providing solutions to financial needs so that it can run well this needs to be supported by human resources with good performance. In the banking industry, it is absolutely necessary to support human resources with good performance in order to achieve the employee's vision and mission. In carrying out its function as a means of intermediation that collects public funds (funding) and channeling it back (lending) so that it can contribute to economic drivers.

In achieving its objectives, banking companies absolutely must have quality human resources and good performance. Employees as human resources in a banking company must always be able to produce a good performance in accordance with company expectations. Organizational culture, leadership, and motivation are some of the factors that influence employee performance in achieving company goals. Besides compensation, job security, promotion, reward, and punishment are expected to be able to encourage a banking company employee to have high performance. According to Stoner, 2018: 14), "performance is the quantity and quality of work completed by individuals, groups or organizations". Crossman, A., \& Bassem, A.-Z. (2003) Performance refers to employee performance which is measured based on the standards set by the company and certainly becomes a proof of one's success in carrying out a job. The success of achieving employee goals is very dependent on the performance of human resources. Banking company employees who are able to compete in an era of competitive competition are employees who are responsive to all services provided in banking products that are currently demanded to be reliable human resources and capable of directing the achievement of high performance, as well-organized human resources. The existence of employees in the future will face many challenges, therefore it is demanded to be able to develop their human resources in order to produce a 
good performance. This is very useful for the continuity and progress of employees on an ongoing basis.

Strong organizational culture and leadership in the banking world is an absolute thing in an organization (Oluwafemi, E. I. 2017), because organizational and leadership culture is one of the determinants of direction and goals of employees who can direct and manage human resources to achieve employee goals. According to C, Ratnasih. 2017 "leadership is a process of one's activities to move others by leading, guiding, influencing others, to do something in order to achieve the expected results". Leadership is able to influence people who are domiciled or followers who are led to do something in order to achieve certain goals. Leadership is a driving force in an organization to achieve effectiveness in carrying out tasks, as well as organizational culture. The role of leadership is vital in determining the achievement of predetermined goals and influencing in determining employee goals, motivating behavior that is led to achieving goals, and influencing in driving performance. Good leadership can create pleasant conditions for subordinates in carrying out work so as to produce a good performance.

Motivation becomes a motivator to do or achieve a goal. Oluwafemi, E. I. (2017). states "motivation is the condition in a person who drives the desire of individuals to carry out certain activities in order to achieve goals". Employee motivation and compensation received is a driver of work, according to Robbins, Stephen P \& Timothy A. Judge. 2009 can simply be distinguished two forms of work motivation, intrinsic and extrinsic motivation. Intrinsic motivation comes from within the person himself, such as there are awareness and willingness to do or do something. While extrinsic motivation comes from elements outside the work inherent in the job to be the main factor that makes a person motivated such as status or compensation. Employees who are highly motivated will carry out their work to the maximum extent possible and are confident that by achieving employee goals and objectives, their personal interests will be fulfilled. This will certainly affect the success and achievement of good performance in banking employees in Indonesia.

As for work, an employee expects job security as comfort in working and does not worry about the future of his career, and promotion to a higher level. Besides the importance of the variable reward and punishment to increase employee morale.

\section{LITERATURE REVIEW}

Various opinions about the definition of human resource management, among others: some create human resources, there are interpreted as manpower management, and there are those who equate with personal (personnel, staffing, and so on). But in human resource management that may be appropriate is human resources management (human resource management), thus simply understanding the management of human resources is managing human resources Dessler, Gary. 2013. Definition of human resource management according to Armstrong (in Triton, 2010: 17) are: Human resource management can be defined as a strategic and coherent approach to managing the organization's most valuable assets, people who work in organizations, both individually and collectively, and make contributions to achieve organizational goals.

Employees of organizations in the field of human resources certainly want to have quality human resources in the sense of fulfilling competencies to produce productivity and good performance so that they can realize their vision and achieve employee goals. Performance is very instrumental in determining the sustainability of employee activities. Employee performance is a condition that is displayed in full by the employee for a certain period.

Employee performance is the result or achievement that is influenced by the operational activities of employees, especially banks in utilizing their resources. According to Vincent Gasperz (2005), the purpose of performance measurement is to produce data, analyzed it appropriately to produce accurate information. Many factors can affect the performance of banking employees in Indonesia, including, there are employees from a financial perspective and there are employees from a non-financial perspective. As 
discussed in this study are the factors that influence it in terms of non-financial are organizational culture, leadership, employee motivation, compensation, job security, promotion, reward, and punishment. In the influence of organizational culture on performance, Wibowo (2011: 363) said a study that had been conducted showed that an organization that changes organizational culture can improve its performance very significantly compared to organizations that do not change organizational culture. However, not all cultural changes produce results if they are not done well.

While in the relationship of leadership to performance (Edy Sutrsino, 2009) states leadership plays a dominant, crucial, and critical role in the overall effort to improve work performance/performance, both at the individual level, at the group level, and the organizational level. Meanwhile, in the influence of employee motivation on performance, Triton (2010: 165) says that motivation is related to the level of effort done by someone to pursue a goal, motivation is closely related to satisfaction and performance. Furthermore regarding compensation according to Hasibuan (2015) is all employee income in the form of money or goods directly or indirectly in return for services rendered to employees.

According to Maslow's theory of needs in Robbins and Thimoty (2009), it is explained that within each human being there are five hierarchies of needs, namely physiological needs, security needs, social needs, appreciation needs, and self-actualization needs. Of these five needs, there is a need for security which includes a sense of wanting to be protected from physical danger. Furthermore, in terms of promotion or career path and general employment conditions and long-term career opportunities in the banking world (Brog and Elizur, 1992).

It also needs to be said about rewards and punishments which are material or nonmaterial awards given by employees to their employees. Whereas punishment is the opposite of a reward. Punishment is a punishment or sanction that is used by employees to change employee behavior in considering time, intensity, schedule, clarification, and impersonality.

\section{METHODS OF RESEARCH}

Based on the measurement of research data, this study uses quantitative research. According to E.G. Carmines and R.A. Zeller (in Etta MamangSangadji and Sopiah, 2010: 26) "quantitative research is research whose data are expressed in numbers and analyzed by statistical techniques". This study was conducted to determine and explain the influence of independent variables with dependent variables partially and simultaneously. Based on the explanation above, a framework can be arranged research as follows:

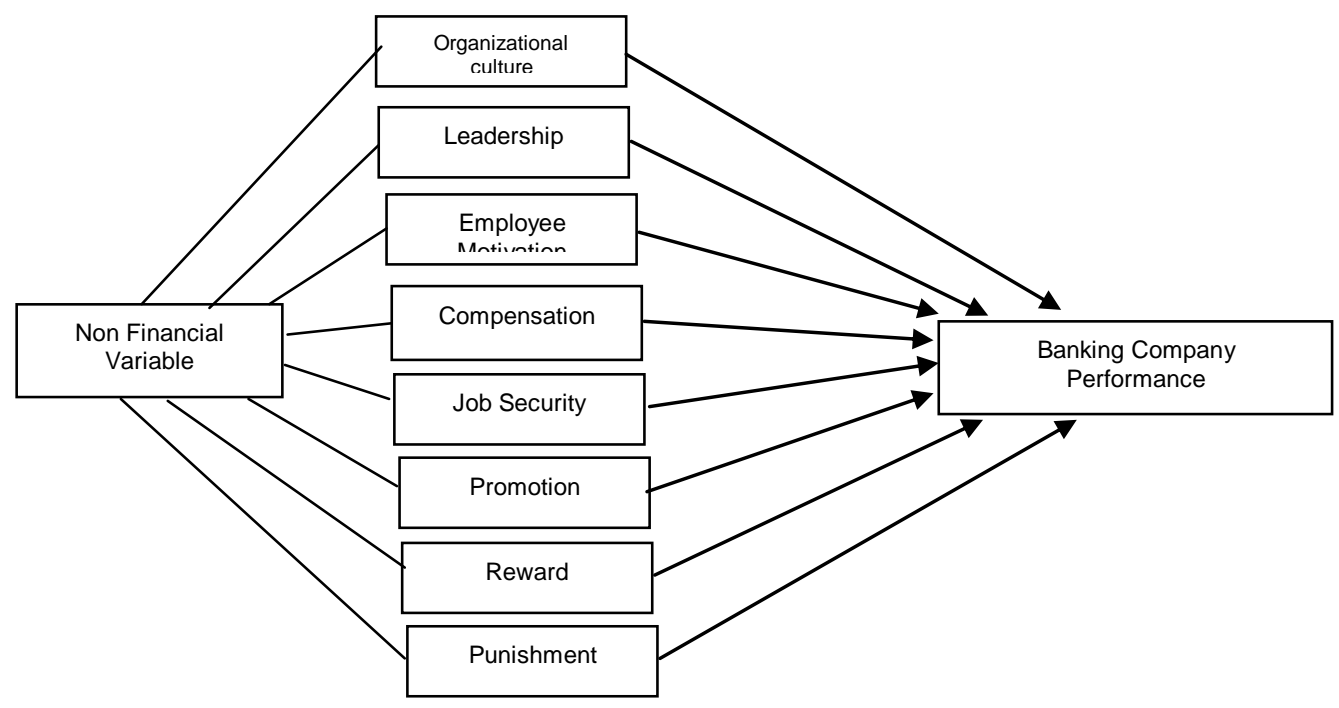

Figure 1 - Conceptual Framework 
The independent variables in this study are Organizational Culture (X1), Leadership (X2), Employee Motivation (X3), compensation (X4), job security (X5), promotion of position $(X 6)$, reward $(X 7)$, and punishment $(X 8)$. The dependent variable in this study is the performance of banking employees $(\mathrm{Y})$.

In operating the variables above, the Likert scale is used in this study. According to Nur Indriantoro and Bambang Supomo (2009: 104) "Likert scale is a method that measures attitudes by expressing their agreement or disagreement with a particular subject, object, or event". By using a Likert scale, the variables to be measured are translated into dimensions, dimensions are translated into sub-variables and then sub-variables are translated again into measurable indicators. Finally, these measurable indicators can be used as starting points for making instrument items in the form of questions or statements that need to be answered by respondents. Each answer is connected with the form of a statement or attitude support expressed in the following words (Riduwan and Engkos Achmad Kuncoro, 2011: 20); Positive Statement: Strongly Agree $(\mathrm{SS})=5$, Agree $(\mathrm{S})=4$, Neutral $(\mathrm{N})=3$, Disagree $(\mathrm{TS})=$ 2, Strongly Disagree (STS) $=1$.

Wibowo (2011: 19) defines "organizational culture is the basic philosophy of the organization that contains beliefs, norms, and shared values which are the core characteristics of how to do things in the organization". Beliefs, norms, and values it becomes the handle of all human resources in the organization in carrying out its performance.

In quantitative research, data analysis is an activity after the data from all respondents have been collected. Activities in data analysis are: grouping data based on variables and types of respondents, tabulating data based on variables from all respondents, presenting data for each variable studied, doing calculations to answer the problem formulation, and doing calculations to test hypotheses that have been proposed. Data analysis techniques in quantitative research use statistics. There are two kinds of statistics used for data analysis in research, namely descriptive statistics and inferential statistics (Sugiyono, 2010: 206).

A research instrument is a tool used by researchers to measure natural and social phenomena. Some instruments are already available and which are not yet available, most instruments that are already available have been tested for their reliability and validity, while those not yet available must be tested for their reliability and validity. According to Sugiyono (2010: 207) "inferential statistics are statistical techniques used to analyze sample data and the results are applied to populations". Data analysis techniques with inferential statistics try to use multiple linear regression analysis used to determine the effect of independent variables on the dependent variable.

Multiple linear regression analysis is a linear relationship between two or more independent variables $\left(\mathrm{X}_{1}, \mathrm{X}_{2}, \ldots . \mathrm{X}_{\mathrm{n}}\right)$ with the dependent variable $(\mathrm{Y})$ (Dwi Priyatno, 2008: 73). This analysis is to determine the direction of the relationship between the independent variable with the dependent variable whether each independent variable is positively or negatively related and to predict the value of the dependent variable if the value of the independent variable has increased or decreased.

The multiple linear regression equation for 8 predictors is as follows:

$$
Y^{\prime}=a+b_{1} X_{1}+b_{2} X_{2}+b_{3} X_{3}+b_{4} X_{4}+b_{5} X_{5}+b_{6} X_{6}+b_{7} X_{7}+b_{8} X_{8}+e
$$

Where: $Y^{\prime}=$ Variable Performance of banking employees; $X_{1}=$ Organizational Culture Variable; $\mathrm{X}_{2}=$ Leadership Variable; $\mathrm{X}_{3}=$ Employee Motivation Variable; $\mathrm{X}_{4}=$ Compensation Variable; $\mathrm{X}_{5}=$ Job security variable; $\mathrm{X}_{6}=$ Promotion Variable; $\mathrm{X}_{7}=$ Reward Variable; $\mathrm{X}_{8}=$ Variable Punishment; $\mathrm{a}=$ constant; $\mathrm{b}_{1}$ to $\mathrm{b}_{8}=$ regression coefficient; $\mathrm{e}=$ disturbance term / error term, the values of other variables not included in the equation.

Multiple correlation analysis is used to determine the relationship between two or more independent variables $\left(\mathrm{X}_{1}, \mathrm{X}_{2}, \ldots, \mathrm{X}_{\mathrm{n}}\right)$ to the dependent variable $(\mathrm{Y})$ simultaneously (DwiPriyatno, 2008: 78). This coefficient shows how big the relationship that occurs between the independent variables $\left(\mathrm{X}_{1}, \mathrm{X}_{2}, \ldots, \mathrm{X}_{n}\right)$ simultaneously against the dependent variable $(\mathrm{Y})$. $R$-value ranges from 0 to 1 , the value is getting closer to 1 means that the relationship is 
getting stronger, on the contrary, the value is getting closer to 0 , and the relationship is getting weaker. Guidelines for interpreting the correlation coefficient as follows: $0,00-0,199$ $=$ Very Low, $0,20-0,399=$ Low, $0,40-0,599=$ Medium, 0,60 - 0,799 $=$ Strong, 0,80 $1,000=$ Very Strong.

Analysis of determination in multiple linear regressions is used to determine the percentage contribution of the influence of independent variables $\left(X_{1}, X_{2}, \ldots X_{n}\right)$ simultaneously to the dependent variable (Y) (DwiPriyatno, 2008:79).

This coefficient shows how much percentage of the variation of the independent variables used in the model is able to explain the variation of the dependent variable. R2 is equal to 0 , so there is not the slightest percentage of the effective contribution given by the independent variable to the dependent variable, or the variation of the independent variable used in the model does not explain the slightest variation in the dependent variable. Instead, $\mathrm{R} 2$ is equal to 1 , then the percentage of the contribution of influence given by the independent variable to the dependent variable is perfect, or the variation of the independent variable used in the model explains $100 \%$ of the dependent variable variation.

\section{RESULTS OF STUDY}

Data normality test is carried out in two ways, namely a histogram for the Standardized Residual distribution or a Normal Probability Plot graph for each model. To obtain accurate results, calculations are performed using SPSS Version 21 software, the results of the Normal Probability image show that the distribution of data on the chart has a strong correlation between Expected Cumulative

Probability and Observed Cumulative Probability so that it meets the normality requirements. The normal graph of the pattern shows the spread of points around the diagonal line, and following the direction of the diagonal line indicates the regression model meets the normality assumption.

A multicollinearity test is performed to determine whether the independent variables tested are truly free. The method used is to calculate VIF (Variance Inflation Factor). From the calculation of SPSS 21, the tolerance values and VIF values for each stage of the study are as follows:

Table 1 - Multicollinearity Test

\begin{tabular}{|l|l|l|l|}
\hline No. & Variables & Tolerance Value & VIF Value \\
\hline 1. & Organizational Culture $\left(\mathrm{X}_{1}\right)$ & 0,528 & 1,892 \\
\hline 2. & Leadership $\left(\mathrm{X}_{2}\right)$ & 0,530 & 1,886 \\
\hline 3. & Employee Motivation $\left(\mathrm{X}_{3}\right)$ & 0,470 & 2,128 \\
\hline 4. & Compensation $\left(\mathrm{X}_{4}\right)$ & 0,539 & 1,791 \\
\hline 5. & Job security $\left(\mathrm{X}_{5}\right)$ & 0,327 & 2,916 \\
\hline 6. & Promotion $\left(\mathrm{X}_{6}\right)$ & 0,421 & 2,321 \\
\hline 7. & Reward $\left(\mathrm{X}_{7}\right)$ & 0,561 & 1,622 \\
\hline 8. & Punishment $\left(\mathrm{X}_{8}\right)$ & 0,486 & 2,073 \\
\hline
\end{tabular}

Source: Data processed by researchers.

From table 1 it can be seen that the VIF value $<5$, it can be said that there is no multicollinearity between the independent variables of organizational culture $\left(X_{1}\right)$, leadership $(X 2)$, employee motivation $\left(X_{3}\right)$, compensation $\left(X_{4}\right)$, Job security $\left(X_{5}\right)$, promotion $\left(X_{6}\right)$, reward $\left(X_{7}\right)$, and punishment $\left(X_{8}\right)$. Thus the multiple regression line model used for 8 independent variables to 1 dependent variable is appropriate.

Heteroscedasticity Test is used to check whether the $Y$ data distribution is random for each $X$ variable value. For the purpose of the test, a Partial Regression Plot Diagram is made between the predicted value and the residual, the results can be revealed that the data is scattered around the number 0 ( 0 on the $Y$-axis), and not forming a certain pattern or trend line. Thus, the data can be said to be Homoscedasticity (absence of heteroscedasticity symptoms) and meet the requirements for regression analysis. 
From the results of calculations using SPSS 21, the effect of independent variables on the bound obtained Durbin Watson (d) statistical value of 1.983. For more details can be seen in the following table:

Table 2 - Model Summary ${ }^{b}$

\begin{tabular}{|l|l|l|l|l|l|}
\hline Model & $\mathrm{R}$ & R Square & Adjusted R Square & Std. Error of the Estimate & Durbin-Watson \\
\hline 1 & $.863^{\mathrm{a}}$ & .745 & .701 & 4.113 & 1.983 \\
\hline
\end{tabular}

a. Predictors: (Constant), Organizational culture, Leadership, Employee motivation, Compensation, job security, promotion, reward, punishment.

b. Dependent Variable: Employee performance.

\section{DISCUSSION OF RESULTS}

There is a significant influence on organizational culture $\left(X_{1}\right)$, leadership $\left(X_{2}\right)$, employee motivation $\left(X_{3}\right)$, compensation $\left(X_{4}\right)$, Job security $\left(X_{5}\right)$, promotion $\left(X_{6}\right)$, reward $\left(X_{7}\right)$, and punishment $\left(\mathrm{X}_{8}\right)$ on the performance of banking employees in Indonesia. This can be seen from the $F$ test results with significant / probability $(0,000)<\alpha(0.05)$ and Fcalculate $(9,274)>$ F-table $(2,883)$, these results indicate that together the results of multiple regression equations are:

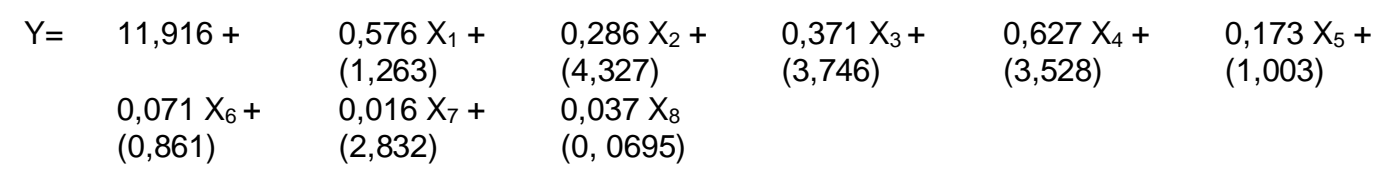

Value $R=0.863$ which means the influence of organizational culture, leadership, and motivation together have a very strong relationship to performance. The coefficient of determination / R2 $=0.745$, this value can be defined that $74.5 \%$ of the performance variables can be explained by organizational culture, leadership, employee motivation, compensation, job security, promotion, reward and punishment together, the remaining $25.5 \%$ by other variables not included in the study.

Partially, there is a significant influence of leadership variables on the performance of banking company employees in Indonesia. This can be seen from the results of the t-test for $\mathrm{X}_{2}$ with a significant / probability $(0,000)<\alpha(0.05)$, and count $(4,327)>\mathrm{t}$-table $(2,032)$, these results indicate that leadership has a significant influence on the performance of banking company employees.

There is a significant influence on employee motivation variables on bank employee performance. This can be seen from the results of the t-test for $X_{3}$ with a significant / probability $(0,000)<\alpha(0.05)$ and $t$-count $(3,746)>t$-table $(2,032)$, these results indicate that employee motivation has a significant influence on the performance of banking company employees.

There is a significant influence of compensation variables on the performance of banking employees. This can be seen from the results of the t-test for $\mathrm{X}_{4}$ with a significant / probability $(0.003)<\alpha(0.05)$ and t-count $(3,528)>t$-table $(2,032)$, these results indicate that compensation has a significant effect on the performance of banking employees.

There is a significant influence of the reward variable on the performance of banking employees. This can be seen from the results of the t-test for $X_{7}$ with a significant / probability $(0.003)<\alpha(0.05)$ and $t$-count (2.832) $>\mathrm{t}$-table (2.032), these results indicate that compensation has a significant effect on the performance of banking company employees.

Of the four variables above get significant results on the performance of banking company employees, therefore it is necessary to get special attention from banking companies, while for organizational culture variables $\left(X_{1}\right)$, Job security $\left(X_{5}\right)$ is not significant according to the results of research, promotion $\left(X_{6}\right)$, and punishment $\left(X_{8}\right)$ the results are not significant. 


\section{CONCLUSION} follows:

Based on the discussion of the results of the study conclusions can be submitted as

1. From the results of data processing as a whole of all variables in a row variable organizational culture $(X 1)$, leadership (X2), employee motivation (X3), compensation (X4), Job security (X5), promotion (X6), reward (X7), and punishment (X8) is significant on the performance variable of banking employees in Indonesia.

2. Partially, there is a significant influence of the leadership variable $\left(X_{2}\right)$ on the performance of banking employees.

3. Partially there is a significant influence of employee motivation variable $\left(X_{3}\right)$ on the performance of banking employees.

4. Partially, there is a significant influence of the compensation variable $\left(\mathrm{X}_{4}\right)$ on the performance of banking employees.

5. Partially, there is a significant effect of the reward variable $\left(X_{7}\right)$ on the performance of banking employees.

6. As for the organizational culture variable $\left(X_{1}\right)$, Job security $\left(X_{5}\right)$, promotion $\left(X_{6}\right)$, and punishment $\left(\mathrm{X}_{8}\right)$ it is not significant. Therefore these variables do not need special attention.

\section{REFERENCES}

1. Beatrice, D., Patrick, B. O., \& Bulitia, G. M. (2016). Analysis of Quality Management Practices and Organizational Performance of Private Healthcare Facilities in Nairobi County, Kenya. International Journal of Novel Research in Marketing Management and Economics, 3(3), 115-125.

2. C, Ratnasih. 2017. Leadership, Dicipline, Motivation and Implications On Teachers Performance, IJHCM (International Journal Of Human capital Management) 1 (01), 124 $135 \mathrm{Vol}, 2017$.

3. Crossman, A., \& Bassem, A.-Z. (2003). Job Satisfaction and Employee Performance of Lebanese Banking Staff. Journal of Managerial Psychology, 18(4), 368-376.

4. Daft, Richard L. 2010. Organization Theory and Design, 10th Edition. Mason.Ohio: Cengage Learning

5. Dessler, Gary.2007. Manajemen Sumber Daya Manusia (Jilid 1). Jakarta: Indeks

6. Dessler, Gary. 2013. Human Resource Management 8 th. New Jersey; Prentice Hall International, Inc.

7. Dessler, Gary. 2003. Human Resource Management. Tenth Edition. New Jersey: Prentice-Hall, Inc. Alih Bahasa oleh Paramita Rahayu, 2006, PT. Indeks, Jakarta.

8. Gelinas, Patrice. (2005). Redefining total compensation to include the value of job security. Ivey business journal, pg 1

9. I, Rosyadi. (2019). Faktor penentu Employee Performance (kasus perusahaanperusahaan Jasa Asuransi di Indonesia), Jurnal Ekonomi, Vol. 21 Nomor 3, Oktober 2019, Pascasarjana Universitas Borobudur.

10. Lukman Dendawijaya. (2009).Manajemen Perbankan. Ghalialndonesia, Jakarta.

11. Martoyo, Susilo. 2007. Manajemen Sumber Daya Manusia. Edisi Kelima. Yogyakarta: BPFE Universitas Gajah Mada.

12. Oluwafemi, E. I. (2017). Understanding Organizational Culture and Organizational Performance: Are They Two Sides of the Same Coin? J. of Management Research, 9(1).

13. PB, Triton. 2010. Manajemen Sumber Daya Manusia: Perspektif Partnership and Kolektivitas. Cetakan Pertama. Jakarta: Oryza.

14. Rivai, Veithzaldn Andra Permata Veithzal. 2006. Credit Management Handbook: Teori Konsep, Prosedur and Aplikasi Panduan Praktis Mahasiswa, Bankir and Nasabah, PT Raja Grafindo Persada, Jakarta.

15. Robbins, Stephen P \& Timothy A. Judge. 2009. Perilaku Organisasi, Edisike 12, diterjemahkan oleh: Diana Riadan Abdul. Jakarta, Salemba Empat. 
16. S, Saji.,C, Ratnasih. 2018. The Model Which Determines Job Satisfaction (Case On Company Employees In Indonesia, Conference Proceedings Jakarta Indonesia, ICABE 2018 Vol. 2018.

17. Sutrisno, Edy. 2009. Manajemen Sumber Daya Manusia. Edisi Pertama. Jakarta: Kencana Prenada Media Group.

18. Wibowo.2011.Budaya Organisasi: Sebuah Kebutuhan untuk Meningkatkan Kinerja Jangka Panjang. Edisi Pertama. Jakarta: PT. Rajagrafindo Persada.

19. Wibowo. 2011. Manajemen Kinerja. Cetakan Keempat. Jakarta: PT. Raja grafindo Persada.

20. Wijayanto, Dian. 2012. PengantarManajemen. Jakarta: PT. Gramedia Pustaka Utama.

21. Yukl, Gary. 2001. Leadership in Organization. Fifth Edition. NeKasmir. (2008). Manajemen. 